Portland State University

PDXScholar

Applied Linguistics Faculty Publications and

Presentations

$1-1-2003$

\title{
Fergie's prescience: the changing nature of diglossia in Tunisia
}

Keith Walters

Follow this and additional works at: https://pdxscholar.library.pdx.edu/ling_fac

Part of the Anthropological Linguistics and Sociolinguistics Commons

Let us know how access to this document benefits you.

\section{Citation Details}

Walters, K. (2003). Fergie's prescience: the changing nature of diglossia in Tunisia. International Journal Of The Sociology Of Language, 2003(163), 77-109.

This Article is brought to you for free and open access. It has been accepted for inclusion in Applied Linguistics Faculty Publications and Presentations by an authorized administrator of PDXScholar. Please contact us if we can make this document more accessible: pdxscholar@pdx.edu. 


\section{Fergie's prescience: the changing nature of diglossia in Tunisia}

KEITH WALTERS

\section{Abstract}

Despite criticisms it has received, Ferguson's (1959b) account of diglossia should be recognized for its prescience. It offered not only an admittedly idealized characterization of diglossia in Arabic, but also pointed out how and why it might change. Focusing on Tunisia, this article demonstrates the many ways in which Fergie was right. It examines the changing demographics of Tunisians' access to the high variety of Arabic; the complex ways in which Tunisians, and Arabs more generally, deal with the "communicative tensions" diglossia creates; and considers the changing nature of Arabic in what is, in many ways, a postdiglossic Tunisia.

Perhaps the most interesting thing about Ferguson's (1959b) paper on diglossia is its prescience: even when Fergie wasn't quite right, his work pointed future researchers in what have turned out to be especially profitable directions. His discussion was grounded in what he admitted to be an idealized description of four very different cases of a particular relationship between the standard, or "high," variety of a language and the other, or "low," less overtly prestigious variety of the same language within a speech community: Arabic, Modern Greek in its relationship to katharévusa, Swiss German in its relationship to High German, and Haitian Creole in its relationship to what we might term standard metropolitan French. ${ }^{1}$ Following William Marçais (1930, 1931a, 1931b), Ferguson termed this relationship "diglossia." As careful readers of the paper will recall, however, Ferguson's goal was not to offer a complete description of Arabic or Arabic diglossia (or any kind of diglossia). Rather, his goal was to understand the ways in which diglossia represents one possible configuration, often a transitional one, in language standardization, the processes whereby some languages come to have a standard variety (or more properly, varieties) while others do not. In so doing, Fergie altered the trajectory of research on Arabic and, to varying degrees, these other languages. 
But much has changed in the Arab world in the forty-odd years since the paper was first published, a situation Ferguson foresaw. In this article, I seek to build on Ferguson's original characterization of diglossia in Arabic in order to explore some of the ways that Arabic diglossia in Tunisia continues to change and that, in many senses, it is more accurate to characterize Arabic in Tunisia as postdiglossic. Specifically, I focus on two topics demonstrating the changes that have taken place. First, using data from the 1994 census, I examine the changing demographics of Tunisian society with respect to speakers' access to the fusha, or high variety of Arabic, in order to demonstrate that, as Fergie would predict, when diglossia changes, it does so in predictable ways, given the particular details of the social and linguistic context and what we might term certain sociolinguistic principles. Census data are especially useful here because they permit us to begin to historicize discussions of Arabic speech communities at various times, something that has often not happened in treatments of diglossia and Arabic more generally. Second, I consider the changing nature of the "communicative tensions" existing between the high and low varieties of a language in diglossic settings. In this latter case, my major concern is the "new" varieties of Arabic and the new ways of using Arabic that are becoming increasingly conventionalized in Tunisia.

Conventionalization was one of Ferguson's career-long interests. Ferguson described it as the "process by which members of a community somehow come to share the sound-meaning pairings that constitute their means of verbal communication, in spite of the fact that no two speakers speak exactly the same way and the shared language keeps changing" (1994: 15). He noted further that much about conventionalization remains a mystery to students of language, language change, and sociolinguistics, although a deep understanding of this process is a necessary prerequisite for certain kinds of progress in each of these fields. Having examined Tunisian census data and discussed the current response of Tunisians to the "communicative tensions" inherent in diglossia, I conclude with some remarks on Fergie's contribution to our understanding of Arabic and of diglossia.

\section{Rethinking language description and taxonomies}

Like Ferguson, I will focus much of my discussion on language varieties, that is, linguistic systems that can, on formal linguistic grounds, be distinguished from one another, whether or not members of the speech community might consistently do so in terms of their attitudes or their linguistic production. I take varieties as a point of departure for a much more 
complex problem, the description of speech communities, which Hymes defined as a description of a community's "means of speech and their meanings to those who use them" (1973: 67, emphasis in original). Obviously, Hymes was outlining a much larger task, one encompassing the delineation and description of not only varieties of language, but also the ways in which members of the community use language as well as their understandings of the meanings of both the varieties and the uses to which they are put, issues to which I seek to attend as I write. This latter topic, speakers' beliefs about language varieties and language use, has received great recent attention in research on language ideology (e.g. Woolard 1998; Gal and Irvine 2000), and it seems safe to claim today that certain aspects of Ferguson's characterization of diglossia were, at least with respect to Arabic, as much matters of ideology as of actual practice even in 1959. Such a claim could easily be mounted, for example, against the much criticized list of speech events requiring the high or the low variety of a diglossic language in the section on "Function" (Ferguson 1959b: 329). Ultimately, however, the success of nearly all descriptions of ways of speaking, generally the purview of the ethnography of communication, depends crucially on a thorough understanding of the varieties of language - the communicative resources on which and from which language users can draw - within any given community, and such varieties will be my focus.

Such a task is at some level obviously taxonomic in nature, and taxonomic analysis is not well regarded these days in many intellectual circles. Certainly, a valid complaint about much of the sociolinguistic research of the 1960s and 1970s, including Ferguson's own work and work in the ethnography of communication of the time, is precisely its taxonomic nature. Study after study produced neatly organized figures and diagrams that seem mere brittle reifications of language, language varieties, or ways of speaking when viewed through the lens of contemporary social constructivist analyses, which privilege the contingent, the hybrid, the contested, and the performed - all dynamic. Hence, the task for taxonomists in the postmodern era is not to retreat from categorization but to reconceptualize their task: what we must learn how to do is to produce taxonomies that enable us to talk about the hybrid and the contingent. Such a reconceptualization is especially significant in the case of sociolinguistics because of the nature of our subject of inquiry. Given the material nature of language - it can be described and analyzed in such great detail (whether we think of spectrograms, diagrams of syntactic structures, the quantification of features found in a particular register or dialect, or the measurement of the precision timing of pauses in conversation) - and its inherently variable nature, taxonomies can be useful places to start as 
long as those creating and consuming them understand their nature and their limitations.

Potentially useful in a reconceptualized notion of taxonomy are constructs found in the work of R.B. Le Page (1978; Le Page and TabouretKeller 1985), particularly his metaphors of "focused" and "diffuse," which he has applied to linguistic and social phenomena as different as varieties, norms, communities, and patterns of individual behavior. "Focused" varieties are those for which fairly delineable norms exist. Ferguson would likely have spoken of such varieties as highly conventionalized. Standard varieties represent the most highly focused or conventionalized language varieties. Although standard varieties of a language are variable, their variability is minimal; indeed, the process of standardization implies a conscious effort to minimize the range of linguistic variation in order to maximize the range of communication. Importantly, from this perspective, standardization is the result of willful action: groups with social powerwhether intellectual, political, religious, or some combination of these seek to intervene in the course of the language's history, generally by writing grammars and dictionaries and often legislating contexts for use (frequently through the direct or indirect outlawing of the use of other varieties or languages, especially in institutional contexts). ${ }^{2}$ In contrast, "diffuse" varieties are those characterized by great variability; creoles and pidgins represent the extreme limits of diffuse varieties though diffuse varieties can predictably be found in other settings characterized by social heterogeneity and linguistic contact.

With regard to varieties of Arabic, Le Page would likely say that both Classical Arabic (CA)/Modern Standard Arabic (MSA) and the national dialects of Arabic are focused. Despite their variability, the nature and extent of their variability is predictable and limited, and the systematicity of each is evident. At the same time, the nature and origin of their focusedness differs. Classical Arabic/Modern Standard Arabic, like all written languages that have undergone the process of standardization, has become focused in terms of a prescriptive standard, the norms against which particular uses of the variety are judged as acceptable or unacceptable. ${ }^{3}$ (Indeed, it would be more accurate, following the opening page of Ferguson's discussion of diglossia, to refer to MSA as "Modern Standardized Arabic" and to refer to all "standard" varieties in similar fashion.) The fact that there is more than one school of Arab grammarians or identifiable features of CA/MSA that are linked to the norms of using the fusha associated with particular nations in no way diminishes the high degree of the focusing from the perspective of the prescriptive norm.

The national dialects of Arabic are likewise focused though to a lesser degree than the standard variety, but that focusing is of a very different 
sort. It is a result of speaker practice. In other words, native speakers of each dialect (and more precisely each social variety of each dialect) have clear intuitions (in the sense that formal linguists use the term) about the acceptability of a given utterance in that variety. Further, we can demonstrate, using the tools of quantitative sociolinguistics, that speaker practices converge around certain norms. One can thus speak of Tunisian Arabic, the national dialect, as a focused system and even of a prestige variety of Tunisian Arabic, that spoken by certain tunisois, though this variety has never undergone the processes of standardization described above. Even today, there is no prescriptive tradition of the sort resulting from the language-external processes of standardization associated with the national dialect, a fact that helps account for its openness to borrowing from other languages and its frequent use as matrix variety in codeswitching involving Arabic and a European language. In other words, although Tunisian Arabic and the other national dialects have undergone no formal process of standardization, they are none the less highly focused in nature, but that focusing is different in nature, origin, and degree from the focusing associated with CA/MSA. ${ }^{4}$

\section{What Fergie knew}

Ferguson offered what has become the standard definition of diglossia in the anglophone literature on Arabic: ${ }^{5}$

a relatively stable language situation in which, in addition to the primary dialects of the language (which may include a standard or regional standards), there is a very divergent, highly codified (often grammatically more complex) superposed variety, the vehicle of a large and respected body of written literature, either of an earlier period or in another speech community, which is learned largely by formal education and is used for most written and formal spoken purposes but is not used by any sector of the community for ordinary conversation. (1959b: 336)

Certainly, a problem among linguists and sociolinguists who discuss diglossia but have no direct experience with communities where Arabic is used has been their attention to this idealized definition at the expense of a basic fact about language - languages and speech communities change, sometimes quite quickly — and the rest of Ferguson's own discussion. Indeed, in addition to characterizing the nature of diglossia with regard to Arabic and other languages, Ferguson also enumerated the social and historical conditions that give rise to diglossia and those that might lead to its reconfiguration or disappearance. 


\section{K. Walters}

As Ferguson noted, three conditions are necessary for the creation of a diglossic situation. First, there must be a "sizeable body of literature in a language closely related to (or even identical with) the natural language of the community" (1959b: 338); crucially, this body of literature must be perceived by speakers as embodying foundational values associated with the community. In the case of Arabic, the body of literature represents al-turaath, or 'the inheritance,' indeed, Badawi (1973) labels the highest (i.e. most elevated) of his five levels of Arabic fusha al-turaath, or 'the fusha of the (Islamic) inheritance,' which includes not only the Qur'an, the hadiith, and commentaries on them but also pre-Islamic poetry. This variety corresponds to what is here labeled CA. Although Western-trained students of Arabic generally argue that this variety of Arabic was likely never spoken natively by anyone, they agree it is closely related to the spoken language of the Arabic-speaking community in the Arabian peninsula of the seventh century C.E. (This question was likewise one that interested Fergie [e.g. 1959a].)

Second, there must be a tradition of what, since Goody (1968), has been termed "restricted literacy" in which access to literacy is limited to a small number of elite, often scribes of some sort. Such restricted literacy has characterized the Arabic-speaking world for much of its history and may still characterize pockets of it, but, as the census data from Tunisia presented demonstrate, it no longer obtains in Tunisia. Finally, a "suitable period of time," generally a number of centuries, must pass. As the spoken language, unimpeded by a prescriptive norm or writing, continues to change because of the sorts of processes historical linguists label "natural," and the earlier variety, thanks to the conservative power of written language, literacy, and the prescriptive tradition that often accompanies them, changes little, diglossia arises.

As Mahmoud (1986) rightfully observed, many critiques of Ferguson's discussion of Arabic diglossia have failed to acknowledge that in addition to enumerating the conditions that give rise to this situation, Ferguson likewise noted three conditions that might lead to a change in the perception of a diglossic situation - namely, diglossia's coming to be seen as a problem rather than as merely a fact of a language's and community's life - as well as its potential reconfiguration. These include the spread of literacy for any of a number of reasons; increased communication within the country, whether between regions or social groups, again for any number of reasons, or, finally, the desire for a "national" standardized language, symbolic of "autonomy" or "sovereignty" (1959b: 338).

Each of these three conditions is relevant to the Tunisian situation and has contributed to the reconfiguration of diglossia that continues to take place there. Literacy has spread for economic, social and ideological 
reasons, and the medium for that literacy has been the high variety of Arabic. Like many developing countries, Tunisia has, since independence, devoted an impressive percentage of its national budget to education. A web site maintained by Le Monde Diplomatique, using statistics from the United Nations Development Project, lists the public expenditures on education in Tunisia for 1995-1997 as 7.7 percent of the annual budget; the comparable figure for the United States for the same period was 5.4 percent (http://www.monde-diplomatique.fr/index/pays). This investment in human capital has paid off in that the country has nearly succeeded in its long-term goal of universal education. Hence, as noted, the tradition of restricted or even limited literacy that enabled diglossia to arise and continue as it did for centuries has ended. A desire for increased communication - and communication in Arabic, often written Arabic in administrative domains within the country and across the Arab worldhas likewise contributed to the shifting nature of diglossia. More significant, however, with regard to this criterion is the changing nature of Tunisian identity as Tunisia has moved from being a French colony to a member of the Arab world in a way that was not possible in the late 1950s, when Tunisia had just gained its independence and Ferguson formulated his description of diglossia.

While there has been no serious movement to create a standardized Tunisian Arabic and use it as the basis of a national language, whether spoken or written, there has certainly been support, as in other Arabicspeaking countries, for the use of the high variety of Arabic as a pan-national language and, less overtly, for the development of nationallybased norms for speaking the high variety. Further, the Tunisian government has likely unknowingly taken actions that have ultimately contributed to a focusing of Tunisian Arabic as a spoken variety and to the focusing of the set of practices associated with educated Tunisians speaking the fus ha. Using a practice common in many countries where national bureaucracies are based on French models, the National Ministry of Education posts secondary school teachers, and new teachers are often placed in smaller towns and less desirable areas; such a practice has permitted secondary school students from around the country to be exposed to a range of regional (and to some extent social) accents of Tunisian Arabic and Tunisians speaking Modern Standard Arabic extemporaneously in face-to-face interactions.

The traditional centralization of media, all government-controlled, in Tunis has likewise contributed to this process of focusing and raising awareness of Tunisian Arabic as distinct from other varieties as well as the ways in which Tunisians speak fusha extemporaneously. ${ }^{6}$ Thus, all of Ferguson's criteria regarding social change are relevant in considering 
the changing nature of diglossia in Tunisia; evidence of the consequences of these social changes are nowhere clearer than in data from the Tunisian census.

\section{The Tunisian speech community as represented by census data}

Although Ferguson never discussed data about the number of speakers of any of the language varieties described in his $1959 \mathrm{~b}$ article, it is clear from his work on language planning in developing nations (e.g. 1966, 1967; see also 1991: 227) that he certainly realized that an adequate description of a speech community requires some delineation, however rough, of the number of speakers with access to the various linguistic resources found in the community. As a tool for estimating the access that various sociodemographic groups might have to the varieties of language in use in a speech community, census data have no equal. Although there are undeniably dangers in using apparent-time self-report data about language competence like census data as evidence of the present or past linguistic situation of a country, they represent one of the few resources available to researchers seeking to understand the unequal distribution of linguistic resources across a population at the most general level. ${ }^{7}$

As the data from the 1994 Tunisian census (the most recent) given in Figures 1 and 2 clearly demonstrate, access to the high variety of Arabic, French, and English has changed considerably over the past five decades in Tunisia thanks to the role of education, and this access has had clear consequences for what we might term the "shape" of the Tunisian speech community. Today, the majority of Tunisians - and certainly the vast majority of younger Tunisians - have some access to the fush $a$, a situation that contrasts markedly with the situation in 1959, three short years after Tunisia gained its independence from France. Figures 1 and 2 provide data on the percentage of males and females, respectively, claiming to be able to read and write the fușha, French, and English. Since the data graphed are percentages, the percentage of illiterates for any age cohort is simply 100 percent minus the percentage claiming Arabic (i.e. the "missing" portion of each "Arabic" bar) because more respondents claimed knowledge of written Arabic than any other language. Although students of Arabic and Arabic diglossia have discussed these topics without reference to the existence of European languages (or indigenous languages like Berber) found in Arabic-speaking communities, I contend that such an approach, while understandable given the traditions of scholarship on the various languages involved and the nature of linguistics as a discipline, is 


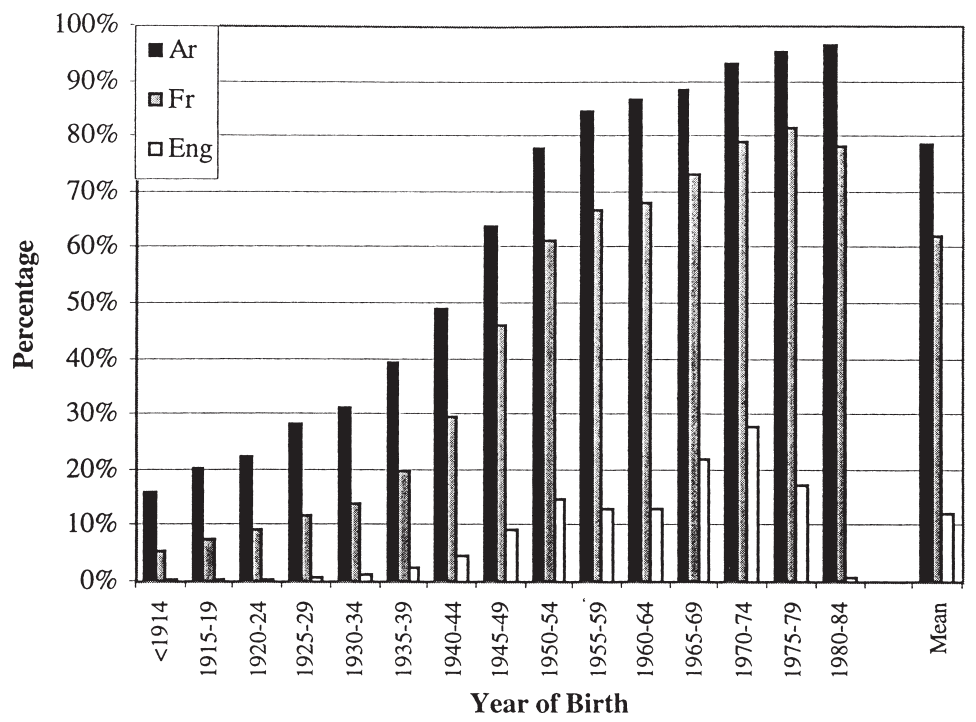

Key: $\quad$ Ar $=$ Classical Arabic $/$ Modern Standard Arabic

$\mathrm{Fr}=$ French

Eng $=$ English

Figure 1. Languages written and read by males in Tunisia by year of birth aged 10 and older, by percentage (1994)

Source: République Tunisienne (1996: 5-6, Table 1.1,1.2)

ultimately counterproductive for the sociolinguist whose task is to understand the fate of linguistic varieties, including the interactions among them, in the lives of speakers and speech communities. Ultimately, the fate of Arabic in any community where it is used and the occasions for its possible or likely use are intimately tied up with the other languages found there, their histories in the community, and their status (cf. Ferguson 1991: 224-225). Therefore, the following discussion will include mention of French and English. ${ }^{8}$

The trends to be found in these census data are significant in demonstrating how the Tunisian linguistic situation and hence Arabic diglossia in Tunisia are significantly different than they were in 1959 or 1900. During the past century at least, and likely before, males led females in knowledge of any language gained through formal education. Among those males born before 1914, 16 percent claimed knowledge of the fușha; 6 percent, knowledge of French; and 0.4 percent, knowledge of English; in other words, 84 percent of the male population of that generation was illiterate. This situation contrasts sharply with that of males born 1950-1954, the 


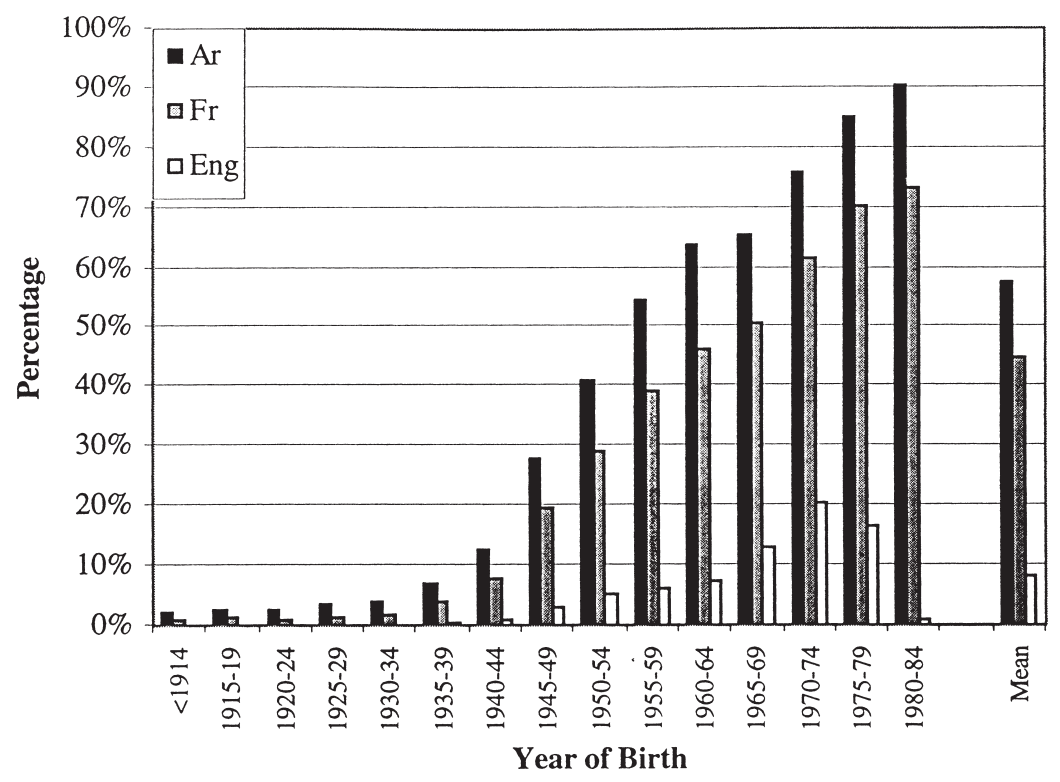

Key: $\quad$ Ar $=$ Classical Arabic $/$ Modern Standard Arabic

$\mathrm{Fr}=$ French

Eng $=$ English

Figure 2. Languages written and read by females in Tunisia by year of birth, aged 10 or older, by percentage (1994)

Source: République Tunisienne (1996: 5,7, Table 1.1, 1.3)

first generation of children schooled after independence; in this case, illiteracy dropped to 22 percent, 78 percent of this cohort claimed knowledge of Arabic, 62 percent claimed knowledge of French, and 15 percent claimed knowledge of English.

Males born a quarter of a century later, between 1975 and 1979, aged 15-19 at the time of the census and members of the cohort that would have been in the second half of secondary school at the time of the census, namely, the grades when one would be studying English, live in a very different Tunisia with respect to knowledge of languages: 96 percent claimed to be able to read and write the fusha, 82 percent claimed knowledge of written French, and 18 percent claimed knowledge of written English. For males born between 1980 and 1984, aged 10-14 and the youngest cohort about which information was collected, the illiteracy rate fell to 3.4 percent as 96.6 percent of this group claimed to have knowledge of the fusha,

Tunisian females have had very different experiences with schooling and, hence, access to the languages of literacy, including the fușha. 
Although males have traditionally had more access to any language learned through formal education, younger generations of females continue to come especially close to catching up with their age counterparts. Given the history of the country, the advancement of females has come far more abruptly than that of males. Among females born before 1914, just over 2 percent claimed the ability to read and write the fuṣha, nearly 1 percent claimed knowledge of written French, and only 0.1 percent claimed knowledge of written English; in other words, nearly 98 percent of this oldest cohort remained illiterate whereas only 84 percent of the corresponding male cohort did. For that generation of females born just before independence, 1950-1954, who might have begun their educations in the school system of an independent Tunisia, 41 percent claimed knowledge of the fusha, 30 percent claimed knowledge of French, and 5 percent claimed knowledge of English. Hence, nearly 60 percent of the women this age were illiterate in comparison with 23 percent of the corresponding male cohort. As these figures indicate, even during its final years, the French colonial regime was hardly committed to education for Tunisian females; this situation altered drastically after 1956, when one of the first priorities of the Bourguiba government was education for all children, especially girls. In contrast, among females born between 1975 and 1979, aged 15-19, the most recent generation to be in secondary school at the time of the census, 85 percent claimed knowledge of the fusha (in contrast to $96 \%$ of the males this age); 70 percent, knowledge of written French; and 16 percent, knowledge of written English. For the next youngest cohort, born 1980 and 1984 and aged 10-14 at the time of the census, the illiteracy rate fell to just under 10 percent as slightly more than 90 percent of the females that age claimed knowledge of the fușha, whereas nearly 97 percent of the males this age had.

In addition to these changes with respect to access to Arabic (and literacy) as well as other languages, it is worth noting other changes with respect to the status of Arabic in particular in Tunisia. Over the course of the past 45 years, the country has moved from having several sorts of schools to a single school system. Under the French, those who received schooling attended kataatiib, or traditional Qur'anic schools (sg. kuttaab); the écoles missions, or schools of the French cultural mission that offered an education equivalent to that offered in the schools of France and taught the fush $a$ as a second foreign language (after English), generally using the grammar translation method and sometimes a teacher of European origin; or the écoles franco-arabes, designed especially for Tunisians, almost always Tunisian boys, where a portion of the curriculum was devoted to the study of Arabic and Islamic studies and teachers of Arabic were often Tunisian. (Boys, in particular, often attended both Qur'anic school and one of the colonial schools.) 


\section{8}

K. Walters

Early in the twenty-first century, Tunisian education is based on an increasingly homogeneous system focusing on Arabic and using Arabic as medium of instruction for all but foreign languages in order to teach a curriculum developed by Tunisians. Primary and secondary school are now completely arabized, and although the study of French is begun in third grade and English in the eighth grade, both are studied as foreign languages, and neither is used as a medium of instruction. Only the smallest minority of Tunisians continue their education in private schools subsidized by the French; partly because of limited skills in the high variety of Arabic, they almost always receive their higher education outside Tunisia. It is not clear what role they will play in the future of an increasingly arabized Tunisia.

Further, it is significant to remember that Figures 1 and 2, which show percentage data, hide the fact that over half the Tunisian population in 1994 was under 23 years of age. Of this population, those below the median age, 85 percent of those 10 or older claimed literacy in Arabic and hence knowledge of the fusha. It is likewise worth noting that in 1999, nearly 85 percent of Tunisian homes reported having television sets, nearly 80 percent radios, and 18 percent satellite dishes (the latter, an increase of 16\% since the 1994 census, Higher Standards for Tunisians). Although Anglo-American linguists, including sociolinguists, have always poohpoohed the notion that the media might have any effect on language, language use, or language change, such a position seems untenable with regard to the Arabic-speaking world. Nearly all Tunisians have passive competence of Egyptian Arabic gained from watching Tunisian television, which continues to rely heavily on programs from Egypt and other Arab countries, and from listening to Egyptian music. (Many Tunisians from the northern part of the country report some competence in Italian, picked up from watching Italian television.) Tunisians likewise know a great deal about other varieties of Arabic, a significant resource when speaking to Arabs from other countries and in Tunisian verbal art (see, e.g., Muhawi 1994 on Tunisian jokes whose punch lines presume knowledge of other varieties of Arabic). Such knowledge will surely increase as satellite dishes become more available and Tunisians tune to programs from across the Arab world and the Middle East Broadcasting Company out of London. (They will, of course, be watching television in other languages, too!) Part of coming to know about and even have passive competence of other national varieties of Arabic and being exposed to citizens of other countries speaking Arabic, including the fuṣha, is developing a heightened awareness of the ways in which Tunisian Arabic and Tunisian linguistic practices differ from those found in other Arab countries - namely, a focusing of norms, contributing to conventionalization. 


\section{Dealing with the "communicative tensions" inherent in diglossia}

Having considered changes in the shape of the Tunisian speech committee resulting in access to both the high variety of Arabic and European languages, let us now turn to the consequences of these changes for the nature of the "communicative tensions" that, as Fergie noted, are an essential part of diglossic communities. In most characterizations of Fergusonian diglossia, the tensions are represented as in Figure 3.

The focus in Figure 3 is the language varieties themselves and the distinctions between them, despite a related linguistic history and the perception by language users that they constitute a single entity - Arabic, in this case. A more careful reading of Ferguson's article, especially one that includes his comments on Arabic, might result in a figure like Figure 4.

Such a recasting of Figure 3 acknowledges some of the most obvious and significant facts about Arabic: the existence of multiple low varieties, often identified as national dialects of Arabic, as well as the existence of something that is neither exactly high nor low but something in between.

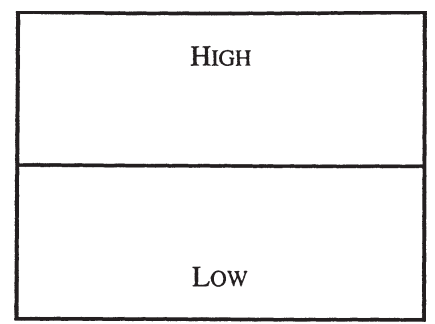

Figure 3. Canonical characterization of diglossia, following Ferguson (1959b)

\begin{tabular}{|c|c|}
\hline & ClASSICAL ARABICl \\
MODERN STANDARD ARABIC (HIGH)
\end{tabular}

Figure 4. More complex view of Arabic diglossia as described by Ferguson (1959b) 


\section{$90 \quad$ K. Walters}

With regard to Arabic and the first of these facts, Ferguson wrote of the existence of "regional [low] standards" such that those hailing from Upper Egypt who become educated are required to learn both the fusha and, "for conversational purposes, an approximation to Cairo L[ow]" (1959b: 332), which many equate with "Egyptian Arabic." In characterizing the second, Ferguson observed that "[t]he communicative tensions which arise in the diglossic situation may be resolved by the use of relatively uncodified, unstable, intermediate forms of the language (... Arabic al-luğah al-wustä...) and repeated borrowing of vocabulary items from H[igh] to L[ow]" (1959b: 332). Commenting specifically on Arabic, he noted the existence of

... a kind of spoken Arabic much used in certain semiformal or cross-dialectal situations [that] has a highly classicized vocabulary with few or no inflectional endings, with certain features of classical syntax, and a generous admixture of colloquial vocabulary. (Ferguson 1959b: 332)

Here, Ferguson collapses two very different communicative situations at least in countries like Tunisia - semiformal situations in which one is speaking with other Tunisians and cross-dialectal situations, where (educated) Tunisians are speaking with (educated) Arabs from other parts of the Arab world. I will return to each of these situations below.

Yet Ferguson's definition of diglossia certainly allows for other formulations, for example, the one offered in Figure 5 where the focus is modality - writing versus speaking — rather than variety alone. Although it fails to acknowledge for the moment the challenges of cross-dialectal

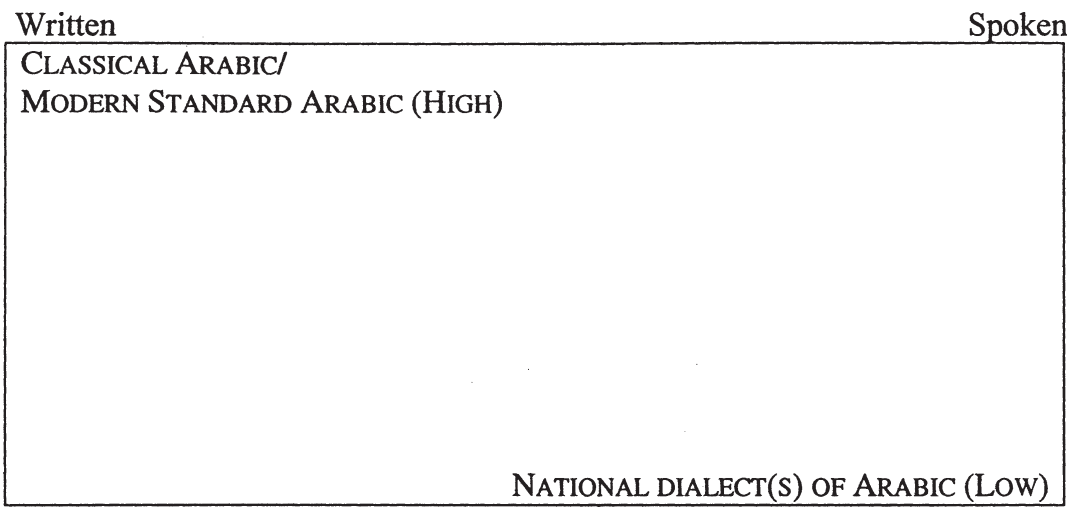

Figure 5. A slightly revised formulation of diglossia, focusing on modality 
communication, the reformulation in Figure 5 throws into relief the source of many of the tensions in diglossic communities. Specifically, it predicts that tensions will arise when language users need to speak the high variety (especially extemporaneously) or write the low variety, and that these tensions will be related to the differing natures of orality and literacy, speaking and writing, and spoken language and written language, respectively. Of course, at the time Fergie wrote his article on diglossia (1959b), linguists had little concern for writing, and many still do not. In the past decades, however, at least in certain quarters, the discipline has begun to examine questions of writing, written language, and literacy. Elinor Ochs (1979), for example, analyzed the nature of planned and unplanned discourse, commenting on the complex ways in which the axis of planning interacts with the axes of speaking and writing, a distinction I exploit in the following discussion. Given the fundamental nature of diglossia, it seems clear that any serious effort to understand the phenomenon must pay close attention to the axis of modality and the axis of planning.

In applying the formulation of diglossia given in Figure 5 in the Tunisian context, we can note that communicative tensions have historically arisen (and continue to arise) when Tunisians find themselves interacting with other Tunisians, whether in speaking or writing, and have wished or needed (or currently wish or need) to draw on the resources, linguistic or symbolic, of the variety of Arabic that "violates" the conventionalized patterns shown in Figure 5. Especially if, following the census date in Figures 1 and 2, we acknowledge the increasingly greater percentage of the Tunisian population that has at least some access to the fush $a$, the primary language of schooling and literacy, we can begin to see why such occasions would arise and imagine the consequences of such situations - those where one needs to speak the high or write the low in contrast to canonical expectations: reading the high variety, whether silently or in settings like news broadcasts, public lectures, or news conferences, and simply speaking the low.

In certain situations, one literally needs to speak the high variety, and if we take the high variety to be the fusha with all its prescriptive tradition, including the use of proper case endings, very few Tunisians are indeed able to do this and do it well. Most, however, have neither the requisite experience nor the constant practice required to speak the high variety extemporaneously for any period of time while consistently observing all of its prescriptive rules. (Lest it be claimed that I am saying that Arabs can't speak Arabic, a charge sometimes leveled at Western commentators on diglossia, I wish to add quickly that few Americans, for example, are able to speak extemporaneously and respect the most conservative canons 


\section{K. Walters}

of English usage, especially with regard to the pronouns that follow indefinites like someone and anyone for more than an utterance or two. Though not a psycholinguist, I feel comfortable claiming that the cognitive complexity of tracking such indefinites in English pales in comparison with the complexity of producing the fușha in real time. I would also note that many speakers of English who are quite capable of tracking their indefinites do not do so for a social reason - to avoid being perceived as priggish or pedantic.) In cases where Tunisians cannot maintain the fușha, they produce a dialectal form or some fudged form that is between the dialect and the high variety. (See Boussofara-Omar 1999, chapter four, for a detailed analysis of these fudged forms and the processes giving rise to them, based on a corpus of Habib Bourguiba's extemporaneous public speeches.) In other words, they use resources from both varieties and engage in a form of codeswitching I have elsewhere termed diglossic switching (1996a, 1996c). In discussing such mixing, I will use the term matrix to refer to the variety that provides the frame or syntactic and inflectional morphological base for an utterance and embedded to refer to the variety providing lexical items or even entire expressions that are inserted into the frame. ${ }^{9}$

With respect to this mixing, one can imagine two logical possibilities: either the high variety serves as the matrix or the low variety serves as the matrix, with the respective remaining variety serving as the embedded variety. These sorts of switching are found in very different situations and are evaluated in very different ways. The first sort — using the high variety as the matrix, embedding elements from the low into it, can often be heard early on in fairly formal situations - for example, certain radio interviews or television programs where there is unscripted discussion. However, such a strong value of solidarity is associated with the dialectal variety, there are multiple motivations for not speaking the high variety, especially when one's interlocutors are also Tunisian. Such an observation helps account for the observation repeatedly made across Arabic-speaking communities that even in fairly formal situations like radio and television interviews, the longer the interlocutors interact, the more likely they are to "drift" toward the dialect (e.g. Schultz 1981).

From a social perspective, one might say that what is going on is that speakers begin by using the high variety, thus establishing their ability to use that variety, and then increasingly (and often quite quickly) use the dialect, reconfiguring the situation from a formal one to one where solidarity plays the greater role. In fact, what happens linguistically in such situations is not that one ends up speaking the dialect, but rather, one ends up using the dialect as the matrix, with frequent embeddings from the high variety, especially for learned terms and certain set expressions, or there 
is matrix-language turnover, often quite rapid, where the matrix language alternates between the two varieties, depending on the utterance. In the case just described, one can assume that the interlocutors are fairly competent in the fușha. ${ }^{10}$ However, one must also acknowledge that some less-schooled and less-skilled speakers attempt to use the high variety even when they are unable to - either in an effort to show off or, more often, because they find themselves in situations where they believe formal language is mandated. Because of the strong prescriptive tradition associated with the high variety, embeddings from the low variety, especially if they violate local norms for such switching with regard to frequency or nature of constituents switched (i.e. if they violate social or structural norms), are generally taken as evidence of inability to speak the high variety well.

Use of Tunisian Arabic as matrix for diglossic switching is, to some degree, the natural outgrowth of the need to talk about matters associated with the world of education and literacy using a variety that is in the course of evolving the means of expression for those purposes. In other words, much as earlier generations of educated Tunisians used French terms and expressions when speaking Tunisian Arabic (often introducing borrowings of French origin into Tunisian Arabic), younger educated Tunisians now often draw on the high variety of Arabic as a lexical resource. The practice of such borrowing has given rise to varieties of Tunisian Arabic spoken by the educated, and especially the children of educated couples, that differ markedly from the variety spoken by the uneducated. These new, class-related varieties of Tunisian Arabic continue to undergo conventionalization, and one of their features is the replacement of dialectal lexical items - sometimes of foreign origin, sometimes simply dialectal terms with lexical items from the high variety of Arabic adapted to Tunisian phonology. Ultimately, however, the consequences of these developments go beyond the lexicon to include manner of expression. Thus, whereas less educated Tunisians speaking the dialect ask whether a person "studied" (i.e. went to school or knows how to read and write), more educated Tunisians ask about someone's "level of culture," calqued on a fuṣha collocation. ${ }^{11}$

Thus, given the social changes of the past five decades in Tunisia, we can note two consequences of one of the communicative tensions inherent in diglossia - the need to speak the high variety or at least use resources associated with it while speaking the low: first, the rise of the practice of diglossic switching and, second, the diversification of the dialect itself. Both of these consequences mean that the low variety is far less homogenous than it was at the time of independence in 1956 or Ferguson's initial characterization of diglossia. 


\section{4}

K. Walters

Importantly, in both these kinds of switching, what is conventionalized is not a new variety of Arabic just as in Arabic/French codeswitching in Tunisia, there is no conventionalized new variety corresponding to what some Tunisians, including Tunisian linguists, have perhaps infelicitously sometimes labeled franco-arabe (cf. Garmadi 1968; Maamouri 1973) or arabe-français (Ounali 1970). Instead, what is conventionalized are fairly focused patterns of switching - that is, sets of language practices, strategies for mixing the two varieties governed ultimately by linguistic principles and social norms about the conditions under which and degree to which switching is appropriate. Such switching is, of course, a major source of borrowings in bilingual communities though little is, in fact, understood about the microsociolinguistic processes of conventionalization whereby such borrowings become integrated.

Returning to Figure 5, the reformulation of diglossia that takes account of medium, let us consider the case of what happens when Tunisians need, for any reason, to write the low variety. ${ }^{12}$ The range of cases here is actually quite varied, though the reasons for their existence are quite logical. The first involves people who have not mastered the high variety but have learned the script and are forced to use their limited literacy skills to write the dialect. When I taught English at high school in a rural area of Tunisia in the mid-1970s, my students, in many cases the first generation to receive education, often reported receiving letters from home written in the dialect from fathers or brothers who had learned the Arabic script but had not mastered the fusha. The second set of cases are those in which one who has knowledge of the fusha needs to write single lexical items or phrases for which there is no exact equivalent in the high variety (or, for which, we might claim, the equivalent from the high variety is not widely known or its use would carry stigma, because the user might be considered pretentious). Examples include the use of dialectal items on menu items (even those that are typed or printed) as well as hand-written receipts. The third set of situations involve those in which the dialect is used for purposes of verisimilitude or authenticity, for example, police reports including reported speech, dialogue in novels, television scripts, cartoons, and plays. ${ }^{13}$ Two telling examples of the latter are the very popular Tunisian plays Fadhel El Jaâibi's Famiilya (Al-Ja'aaiibii 1997) and Taoufiq El-Jebali's Klaam Al-liil (Al-Jabaalii 1997). Both plays are printed in the dialect, as they were performed, but the preface to each, the foreword, and an essay following each play ${ }^{14}$ on its relation to the development of Tunisian theater are all written in the fusha. In these cases particularly, the choice of variety for writing, dialect or fusha, directly indexes genre - script versus academic commentary about the script. A final set of contexts for writing the dialect is ideological in nature. An example here is Hédi Belegh's much discussed 1997 bilingual translation into Tunisian Arabic of Saint-Exupéry's Le 
Petit Prince. With this heavily classicized dialectal translation of The Little Prince, Balegh was admittedly attempting to demonstrate that the dialect could be used for literary purposes, a common goal (and strategy) of those crusading for the status of a variety with little prestige. ${ }^{15}$ In fact, actual uses may combine one or more of these. In the case of police reports, for example, we can imagine that in addition to recording what was actually said in the dialect, many officers would resort to use of the dialect or intermediate forms because they would be unable to produce a "correct" fush $a$ equivalent of the information provided in the dialect, especially when working under the constraints of real-time production.

Having briefly considered tensions that arise within Tunisia as a result of diglossia as Tunisians interact with one another, let us consider briefly the much more complex social and linguistic processes that occur as a response to Tunisians' interacting with those who speak other varieties of Arabic, most often native speakers of Arabic from other countries. As we might imagine, Tunisians in these cases have several options. They can opt to use the high variety, if it is shared. (As noted above, many Tunisians educated during the colonial period, especially women, are completely comfortable in French but unable to read or write the fusha though they may understand much of what they hear and, thanks to experiences in the workplace, are able to employ with ease lexis from that variety when engaging in diglossic switching with Tunisian Arabic as matrix.) Rarely, if ever, however, do Tunisians who could do so choose to use the fușha, a fact that follows, I contend, from the nature of diglossia: the high variety is reserved for formal situations and its use instantaneously and unavoidably turns any situation into a formal one.

Tunisians interacting with non-Tunisian Arabs can also switch to a European language, should one be shared and often report doing so for at least significant portions of many such interactions. The use of a European language permits interlocutors to avoid uncomfortable situations as when, for example, a word in one dialect has negative or obscene connotations in another while precluding the negotiation of the varieties of Arabic to be used. Because so few non-Tunisians have familiarity with that dialect and because of the low esteem in which North African dialects are held by speakers of Arabic to the East, who often claim North Africans "don't speak Arabic," Tunisians, like Algerians and Moroccans, often find using a European language a safer, though by no means neutral, choice for significant parts of interdialectal interactions. (As one might predict, much of the phatic and interpersonal aspects of the interaction are likely to be done in Arabic.)

Finally, Tunisians interacting with non-Tunisians can engage in some sort of switching. Depending on the Tunisian and her/his background and that of her/his interlocutors, the choice might be the use of codeswitching 
with Tunisian Arabic as the matrix and the European language as the embedded variety or vice versa. Or the Tunisian might speak Arabic, using Tunisian Arabic as the matrix with a great deal of embedding from other varieties of Arabic - the high variety and other dialects of spoken Arabic - and sometimes one or more European languages. As MyersScotton's model of social motivations (1993b) predicts, such switching enables Tunisians to construct complex identities, laying claim to the rights and obligations sets indexed by each of the varieties involved in the switching.

These two latter cases - codeswitching involving a European language or diglossic switching involving several varieties of Arabic - are of interest for two reasons. In both cases, Tunisians will avoid lexical or grammatical items ${ }^{16}$ they know to be particular to Tunisian Arabic, and depending on the Tunisian and the exact interlocutors, the switching may involve not only lexical items, but grammatical features from other, more prestigious national varieties of Arabic (e.g. the $b$ - prefix attached to imperfect verbs, used nowhere in Tunisia but found in varieties to the East), as well. Significantly, this latter process, the use of grammatical features from other national varieties of Arabic, does not occur in diglossic switching among Tunisians. In other words, when Tunisians engage in diglossic switching with other Tunisians, the grammar is that of Tunisian Arabic and shows at most negligible influence from the high variety (unless, of course, the high variety is the matrix).

In fact, as Boussofara-Omar (1999) demonstrated, one of the ways in which the grammar of the dialect is influencing the fusha as used by Tunisians is that Tunisians - as well as speakers of other varieties of Arabic - now accept as part of the high variety syntactic patterns that are not part of that variety as defined prescriptively but which occur in dialectal Arabic provided the lexical items in the utterance come from the fusha. Such convergence, especially at the syntactic level, should not be surprising when one recalls that implicit in Ferguson's characterization of diglossia is the observation that it represents a situation of prolonged and persistent language contact involving two varieties of a single language (though researchers and many speakers of Arabic have often assumed any influence between varieties to be unidirectional with the fușha as source of innovation in the dialect).

\section{Post diglossic Tunisia}

Having examined how Tunisians are dealing with some of the communicative tensions arising from diglossia, let us now step back in order to consider the existing varieties and emerging varieties of Arabic used in 
Tunisia as well as the language practices associated with Arabic there as they relate to one another as Hymes (1973) recommended. Doing so will enable us to relate the details of this discussion, especially its focus on modality, to other work that has been conducted in the field of Arabic sociolinguistics. It will also permit us to consider the dynamic interactions among these varieties and practices.

Figure 6 represents the relevant varieties and practices labeling them with names often used in the existing literature on Arabic and locating

Planned

Unplanned or

Extemporaneous

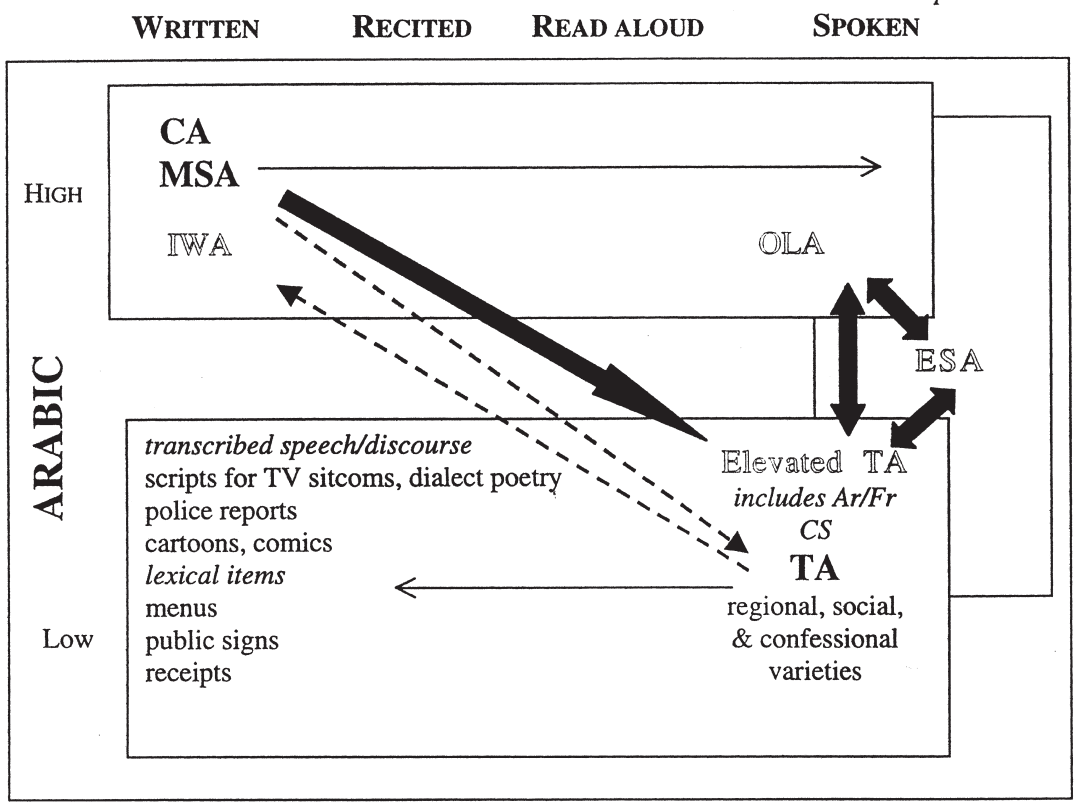

Key: $\quad \mathrm{CA}=$ Classical Arabic

MSA $=$ Modern Standard Arabic

IWA $=$ Informal Written Arabic

OLA $=$ Oral Literary Arabic

ESA $=$ Educated Spoken Arabic

Elevated TA $=$ Elevated Tunisian Arabic

$\mathrm{TA}=$ Tunisian Arabic

Abbreviations in regular font indicate conventionalized varieties; those in an "outline" font indicate practices that have not given rise to fully conventionalized varieties.

Dotted arrows and heavy arrows indicate direction and degree of influence.

Figure 6. Varieties of Arabic and practices involving Arabic in Tunisia as they relate to one another and to modality. 
them with respect to modality and overt prestige. It locates varieties horizontally along a continuum of sorts anchored at one end to writing (and planned discourse), and to speaking (and unplanned or extemporaneous discourse) at the other. Between these two extremes, two other points are delineated, recitation (discussed below) and reading aloud. It locates varieties vertically with regard to their overt prestige and relationship to diglossia in terms of high and low varieties; overtly prestigious varieties are at the top and covertly prestigious varieties are at the bottom. As previously noted, all of the varieties delineated here (perhaps with the exception of Arabic/French codeswitching) are perceived to be part of a single linguistic entity - the Arabic language. In discussing Figure 6, I move from left to right across the top and then across the bottom.

Writing involves the production of written text, whether the text is to be read silently or aloud. Because of the relatively permanent nature of written texts, which permits them to be scrutinized carefully and repeatedly during both their creation and consumption, written texts are generally judged by criteria differing in crucial ways from those used to judge the production of spoken language. In most cases, these criteria are more exacting than those used in evaluating uses of spoken language, especially unplanned spoken language. Similarly, the language variety most often associated with literacy and writing is, almost universally, learned through formal education, and the degree and extent of its mastery linked in complex ways with access to education and ability as well as the tasks one performs in life - some jobs or professions are far more likely to require competence in this variety of "legitimated language" (Bourdieu 1991) than others.

CA/MSA is the variety canonically associated with writing and the creation of written texts in Arabic, especially texts of any value. While this variety and the prescriptive tradition associated with it serve as the standard against which all writing is judged, much that is written, when judged objectively, falls short of these high standards - as is the case with the texts produced in the written varieties of all standardized languages. In addition to these uses of the language - those where writers believe they are using CA/MSA - one finds many others where writers know they are not and may not be seeking to do so. Meiseles (1979) has used the label Informal Written Arabic (IWA) to describe such a register of Arabic. He described such writing as including

extemporaneous writing, the social circumstances around the production of which do not pressure the writer to strictly observe the language quality of his [/her] writing, such as in ordinary interpersonal correspondence, personal records, drafts, and the like. (Meiseles 1979: 273) 
In Tunisia, one certainly finds cases of writing involving the entire range of the register anchored one end to CA/MSA and the dialect at the other. According to the degree of the reader's knowledge of CA/MSA and adherence of the prescriptive tradition associated with it, these texts would be judged as one or the other but are, in fact, often a complex mixture of the two. Thus, the use of IWA here is likely broader than Meiseles intended.

Texts written in CA and texts in MSA can be recited from memory and sometimes are, but the focus of the discussion here is the register used for Qur'anic recitation. As described by Nelson (1985: 14-31), Qur'anic recitation follows tajwiid, or special rules, highly focused or conventionalized, of phonological implementation governing this particular oral performance of written CA as embodied in the Qur'an. Those familiar with the practice are aware that the reciter knows the text from memory - indeed, as Nelson noted, it is the continuing communal practice of recitation, not the written text, that is thought to fix this sacrosanct text. She commented further, "To most Muslims, the Qur'an is equally the written text and its oral rendition, and many have more intimate knowledge of the latter than of the former," a situation contrasting markedly with that of Western Qur'anic scholars, who privilege the text alone (Nelson 1985: 3). It also contrasts with the situation of Christians, whose focus is the written text (or, more properly, translations of the written text) of the Bible.

I include a discussion of recitation here because, as Hymes (1973) rightly insisted, adequate descriptions of speech communities must seek to delineate all the resources speakers have to draw from, and this particular set of practices is a significant one, especially for Arab Muslims who have traditionally seen the link between Arabic and Islam as essential to the nature of each. As one would predict, it likewise becomes a ready resource in interaction for speakers to index Islam, the Qur'an, recitation, or religion, whether in a serious or jocular manner. Thus, the practice of recitation and its social meanings remind us of the culture-specific definitions of notions like "spoken," "written," "recited," and so on. ${ }^{17}$

Reading aloud involves the performing of a CA/MSA text that was previously written. Those familiar with Arab culture know that reading aloud plays a role there in not only education but also other domains that has no exact parallel in American culture (cf. Walters 1996b: 545), for example, and the ability to read Arabic aloud well is taken as clear evidence of the mastery of fușha. Because of the potential ambiguity associated with a writing system that indicates only consonants and long vowels and that is used for a language based on root-and-pattern morphology, the reader is constantly called upon to demonstrate a particular kind of knowledge of the language as well as an ability to access and implement that knowledge on the spot. Reading English aloud makes far different 
sorts of demands because the language's alphabetic script provides all the needed information for decoding except in a limited number of cases (e.g. read as present or preterit or stress in words like produce.)

Speaking the fușha includes efforts to speak MSA extemporaneously. Because of the cognitive complexity of the task, the lack of practice most speakers have with doing so, and the social pressures not to speak the high variety in any but the most formal settings, speakers, even those who can, rarely speak MSA extemporaneously for any length of time. Instead, the result is what Meiseles (1980) has termed Oral Literary Arabic (OLA). Rather than seeing OLA as a variety (or a set of deviations) as Meiseles has, I take it to represent a set of practices that are becoming increasingly conventionalized. As noted earlier, when Tunisians are speaking to other Tunisians in fairly formal settings, what they produce is diglossic switching, characterized by switching between the dialect, TA, and MSA, and by using fudged forms that are not exactly part of either variety. Such switching among Tunisians is giving rise to new class-marked varieties of TA, thereby rendering the dialectal low variety more heterogeneous than it formerly was. Here, I refer to the variety most distinct from the dialect of the uneducated as Elevated Tunisian Arabic. (I am not happy with the label, but the use of "educated" has been preempted for another phenomenon, as explained in the following paragraph.)

When speaking to educated non-Tunisians and using Arabic, educated Tunisians use something close to the Tunisian instantiation of what has been termed Educated Spoken Arabic (ESA) by those working on the Leeds Project (e.g. El-Hassan 1977; Mitchell 1980, 1982, 1986). ${ }^{18}$ These researchers presumed this "standard spoken Arabic" to be an "interArabic koine" and were especially interested in the processes of koineization and standardization (1982: 125); their research focus was Egypt and the Levant. The area labeled ESA in Figure 6 seems to correspond more or less to the range of possibilities in a Tunisian context that Mitchell, who was the project's mentor, referred to as the "Spoken Arabic continuum." Given its location in Figure 6, it should be clear that ESA is, likewise, a set of diverse practices involving switching between TA, MSA, and other varieties of Arabic (as well as, in some cases, foreign languages). The inclusion of "foreign languages" in this description reiterates the challenges of separating linguistic systems from the sociolinguistic practices of individuals who control more than one system.

The varieties of Arabic to which covert prestige accrue are associated with the dialect. Most always associated with spoken contexts that require unplanned or extemporaneous uses of language, the dialect is not an undifferentiated whole. Rather, it identifies Tunisians according to place of birth, religious confession (Sunni Muslim/Jewish), and, as noted, social 
background, most notably, level of formal education. The dialect is also generally the matrix variety for diglossic switching or switching involving European languages, most often French. As described in this paper, new class-marked varieties of the dialect continue to emerge and practices involving switching are increasingly focused even as the contexts in which such switching occurs continue to grow. A result of this focusing is the emergence of highly conventionalized practices - for example, the use of the dialectal rather than the fusha relative pronoun, the use of a single form (the genitive/accusative) for animate noun plurals - that can be said to characterize diglossic switching and even Oral Literary Arabic among Tunisians.

The occasions for writing the dialect are limited although it should be noted that they also are expanding. In addition to its use in literary production (plays or translations), it has also begun to show up in print advertising - both in newspapers and on billboards - in a way that it did not just a few years ago. As would be predicted, such uses are predicated on the dialect's indexing values like trust and those associated with home and hearth or with Tunisianness.

Figure 6 reminds us that rather than thinking of Arabic language use in Tunisia merely as anchored at the two extremes of a continuum, the high and the low, we might profitably think of it within terms of not only high and low but also modality and/or degree of planning. Such an expansion of the diglossic space permits us to represent the range of varieties, practices, and uses associated with Arabic in Tunisia. It also enables us to predict where communicative tensions will arise as a result of diglossia and to investigate and theorize about the nature of the responses to those tensions. While I trust that Figure 6 may ultimately help deepen our understanding of Arabic in Tunisia, Arabic diglossia, and conventionalization, I, like Ferguson, remain in awe of sociolinguistic processes like the latter, whereby Tunisians have in some sense "agreed" to a model of language varieties, practices, and uses much like the one offered in Figure 6.

\section{Conclusion}

The particular consequences of the contact between the high and several low varieties of Arabic, primarily Tunisian Arabic, in Tunisia examined here and the ways in which each has influenced the other and continues to do so would come as no surprise to Fergie. He ended his original characterization of diglossia by making a series of predictions about the future of Arabic and the other languages he discussed around the year 2150. Of Arabic, he wrote, 
Slow development toward several standard languages, each based on an L[ow] variety with heavy admixture of $\mathrm{H}[\mathrm{igh}]$ vocabulary. Three seem likely: Maghrebi (based on Rabat or Tunis?), Egyptian (based on Cairo), Eastern (based on Baghdad?), unexpected politico-economic developments might add Syrian (based on Damascus?), Sudanese (based on Omdurman-Khartoum), or others. (1959b: 340)

His predictions do not seem misdirected with respect to North Africa nearly fifty years after his initial characterization. There is certainly a kind of national prestige variety of spoken Arabic emerging in Tunisia, based on the dialect of Tunis, though the extent of its scope is unstudied. ${ }^{19}$ Arabic has spread in ways and to domains few imagined possible five decades ago, shortly after the time of independence. At the same time, Arabic diglossia is by no means disappearing, and as I have noted elsewhere (1996c), it likely will not - at least no time soon because of issues relating to literacy and writing, issues linguistics in the 1950 s sought to ignore.

Arabic diglossia in Tunisia and elsewhere is, however, being reconfigured in light of particular social factors, as Ferguson noted that it could be. As I explained in the introduction, what we find in Tunisia and elsewhere is, in many regards, a situation that might best be described as postdiglossic. The fuṣha and Tunisian Arabic are ever present, along with other locally much more marginal national dialects of Arabic - all highly focused varieties, or conventionalized, to use Fergie's term. Thus, as Ferguson noted of Arabic diglossia in general, "there is no third pole" (1991: 226). At the same time, one finds clear developments between these two poles because increasingly focused sets of practices involving switching between varieties are giving rise to the growing conventionalization of new varieties like the Tunisian Arabic as spoken by younger Tunisians who are the product of educated parents, especially in urban areas. Such a situation reminds us of the growing unequal distribution of communicative resources in Tunisia, an inequality brought about there, as elsewhere, ironically, by the spread of "universal education" across preexisting axes of social differences, themselves in flux. From a different perspective, the conventionalization of new varieties like Elevated Tunisian Arabic reminds us that, at this point in their history, they are best studied as sets of practices rather than being reified and treated as varieties unto themselves.

This article's examination of, first, Tunisian census data in order to track the spread of access to languages and, second, the ways in which Tunisians have sought to resolve the communicative tensions inherent in the nature of diglossia illustrates another important point, a foundational assumption of poststructuralist research: binaries are ripe for deconstruction, and their deconstruction generally offers significant insight into the nature of the details of the phenomenon being characterized as well as 
the ideology or assumptions of those who created and use the dichotomy. Within the present discussion of the resolution of diglossia's communicative tensions, for example, we are reminded that diglossia has always been more than "writing with the learned, pronouncing with the vulgar" to use a phrase that Mitchell (1982) borrowed from Benjamin Franklin, and that as the demographics of access to the learned variety of Arabic continue to change, we should expect changes in linguistic practices including the fudged forms described by Boussofara-Omar (1999), or the sketch of written uses of the dialect given here. We are reminded further that by understanding these local, sometimes fleeting, and seemingly peripheral or marginal cases of language use, we come to understand the nature of the center or core issues, here the nature of the traditional diglossic dichotomy, in new and deeper ways.

Despite his own admitted commitment to structuralist linguistics, Ferguson and his work pointed us in a poststructuralist direction that has enabled us to begin tackling these issues in ways that are far more analytic than the simple dichotomy, illustrated in Figure 3, to which diglossia is often reduced in sociolinguistics texts. It is Ferguson's insistence on linking the social and the linguistic that characterizes his work and his contributions to Arabic linguistics. Much remains to be understood about standardization, conventionalization, diglossia and Arabic, but our understanding of these phenomena would be far less nuanced than it is today had Fergie not taught us to look at Arabic as he did, looking past the norm-and-deviation paradigm that too often still characterizes discussions of Arabic and all diglossic languages. In so doing, he encouraged us to examine with care specific varieties and specific sets of linguistic practices as ways of better understanding the sociolinguistic processes found across speech communities that at first glance might appear quite disparate. For these gifts, we thank him.

University of Texas at Austin

\section{Notes}

1. Although I had read and taught Ferguson's article numerous times, only while writing this article did I realize that Ferguson had committed a telling error of sorts in listing his cases as an undifferentiated "Arabic" and three "low" varieties of other languages rather than, say, four high or four low varieties. The "error," however, demonstrates the extent to which diglossia characterizes all speech communities where Arabic is the primary spoken and written language.

Like many students of Arabic sociolinguistics, I am a bit uncomfortable with the metaphors that cannot be severed from the labels "high" and "low," preferring instead 


\section{K. Walters}

to think of the respective varieties in other ways - for example, as having overt or covert prestige. I will retain the traditional labels where necessary.

Special thanks to Kirk Belnap, Naïma Boussofara, and Dil Parkinson for feedback on this article at various stages. Thanks also to the many Tunisians who have taught me about their language(s) and societies, and to the institutions that have made my research in Tunisia over the years possible: AIMS, Fulbright, Fulbright-Hayes, SSRC, and the University of Texas at Austin.

2. As should be clear, I part company with Fergie (e.g. 1987) and would be uncomfortable claiming that any of the national dialects of Arabic (except Maltese, an unusual case in other regards) has undergone a process of standardization though the variety spoken by the elite of the capital city of many Arab countries serves as a de facto standard of sorts namely, the prestige spoken variety against which other social or regional varieties are judged and generally found wanting. In other words, this variety has overt prestige whereas other varieties are often overtly stigmatized, at least by those who do not use them. As noted above, I wish to reserve the term "standardization" for particular conscious and interventionist processes in the life cycle of a language, likely always related to literacy in multiple ways.

3. Classical Arabic is, as explained below, the language of the Islamic inheritance whereas Modern Standard Arabic is its contemporary instantiation, which maintains the grammar of CA while boasting a much-expanded lexicon (to accommodate cultural, technological, and scientific innovations). It also shows clear stylistic influences from the European languages, especially French and English, with which it has been in contact over the past few centuries since many Arabs have been educated in the West or read widely in Western languages - press releases must often be translated from European languages, etc. Although this analytic distinction is useful and necessary for some discussions, the two varieties are perceived and treated as one by Arabs. In this essay, I generally use the phrase "the fusha," which means 'the pure' or 'eloquent (Arabic language)', to refer to what Ferguson labeled Arabic's High variety unless I need to distinguish between CA and MSA.

4. The distinctions made in these paragraphs are of some import, I believe. If we accept that both the high and low varieties of Arabic are focused, though in different ways and for different reasons, we can avoid less-than-fruitful discussions of which variety is more "well-defined" or "ill-defined" than the other (pace Kaye 1972). For Le Page and Tabouret-Keller (1985), making such distinctions as "well-defined" and "ill-defined" represents a category error because the notion of "language" as applied to each of the two varieties differs (cf. 1985 188-193).

5. Fishman's expanded notion of diglossia (e.g. 1967) dominates in discussions of diglossia in the Romance languages, including treatments of speech communities like those of North African societies, where Arabic and French earlier occupied clearly functionally differentiated domains, likely because Fishman (1971) was one of the earliest texts in sociolingustics to be translated into French and other Romance languages.

While useful in describing speech communities at a general level, Fishman's expanded notion of diglossia complicates the description of speech communities where one finds Fergusonian diglossia, sometimes called "narrow" diglossia, as well as Fishmanian diglossia. In Tunisia, the relevant languages with respect to the latter are, in one case, Arabic, in contrast to French and other European languages, and, in another, Berber, in contrast to Arabic, French, and other European languages.

6. Over the past decade or so, in particular, both higher education and the media have been decentralized to some degree. There are now regional universities, and regional radio stations (see, http://www.radiotunis.com/news.html, which includes links to each of the regional stations and information about the date of its founding). 
7. In fact, the data represented by the Tunisian census (and likely others) are not in truth "self-report" data. Rather, some older member of the family, who him/herself might not have been highly educated, provided information for the entire family. Despite this fact, I will refer to Tunisians of varying age cohorts as "claiming" knowledge of a language even though, in nearly all cases, someone else claimed it for them. Further, the question eliciting the data analyzed here was almost assuredly designed to obtain information about the level of illiteracy in the population.

8. Data are gathered in the Tunisian census on only "languages written and read"; hence, no data are gathered on Berber or any other languages that a Tunisian might merely speak (e.g. German in areas with many German tourists). Although a number of sources claim that less than one percent of the Tunisian population speaks Berber, there seems to be no existing evidence about the number of Berber speakers. Several Tunisian scholars I've discussed the matter with note that they've simply cited this statistic because it shows up in the writings of the late Salah Garmadi (e.g. 1968). Because Tunisia's current population is 9.5 million, one percent of that population seems much too large on the basis of available impressionistic information.

Berber continues to be used in isolated communities on the island of Djerba and in the extreme south of Tunisia. Speakers of Berber who have received any schooling or worked outside the home community are bilingual in Arabic to some degree; many would also speak French and perhaps some fourth language. Likely because of their small number, there has, in sharp contrast to Morocco and Algeria, been no call for the use of the language in the media or in education.

9. Terms such as "matrix" and "embedded" immediately commit me to the model of codeswitching proposed by Carol Myers Scotton (1993a, 1993b), one that seeks to account for both the social motivations for switching and the syntactic constraints on it within a framework that is, minimally, psycholinguistically plausible. I use this model because of the sorts of insights it offers into the Tunisian sociolinguistic situation while admitting that researchers committed to other frameworks might make slightly different observations about the nature of language mixing in Tunisia. One important insight from her model is that when speakers are engaged in codeswitching, they report they are speaking the matrix language (unless the community has a specific name for the practice of codeswitching, e.g., "Tex-Mex" or "Spanglish" used by many Texas Hispanic bilinguals).

10. Readers can hear just such switching on many of the programs available at http:// www.tunisiatv.com/index1.html, or the current homepage for Radio et Télévision Tunisiennes.

11. Readers who, regardless of native language, have far surpassed their parents or other family members in level of education should understand intuitively the sorts of differences I have in mind as they think about how they explain their research and their work to family members versus colleagues. What is involved are differences in register in the broadest sense, as envisioned by Halliday (e.g. Halliday and Hasan 1989).

12. See Attia (1966) and Hamzaoui (1970) for earlier discussions of writing the Tunisian dialect.

13. In their discussion of Tunisian comic strips, Douglas and Malti-Douglas (1994) pointed out that the dialect occurs in strips or cartoons for adults, not children; comic strips for children use the fush ha, fully voweled, because they are presumed to have an educational purpose.

14. In the essay on Famiilya, the writer switches to the Roman script - for the words "polyphonic" ("however polyphonic in the Bakhtinian sense"), "biomechanical" and "familigia" (in the context of noting the Italian origin of the play's title). The first two are not glossed; the writer assumes that his readers, like him, will be able to switch scripts and languages, a common feature of Arabic prose written for educated Tunisian 
readers. In passing, note as well, that Tunisian Roman-script readers are expected to be able to deal with multiple representations in this script of a single Arabic form as evidenced by the common spelling of these playwrights' names, based on the French orthographic tradition of transliterating Arabic, used in this text and an academic system of transliteration used for listing the works by author's last name in the bibliography.

15. The account of writing in the dialect offered here is overly simplistic in at least two ways. First, it ignores the existence of newspapers completely or partially in the dialect from early in the twentieth century, examples of which can be found in Gliouiz's (1995) study of humor in the Tunisian popular press. Many of these papers, which contain trenchant political commentary and cultural critique, were written in the dialect so that they could be read aloud in cafes around the country. Second, and more seriously, it does not include discussion of the long tradition of writing the dialect of Judeo-Arabic, a confessional variety of Tunisian Arabic, used among Tunisian Jews. Because Jews were for centuries prohibited from writing Arabic script because of its association with Islam, they wrote the dialect of Arabic they spoke using Hebrew characters (Sebag 1996). I suspect that careful study of the history of other Arabic-speaking countries would unearth additional situations complicating the common assumption that there is no tradition of writing the dialect.

16. For example, Tunisian Arabic has a single second-person singular pronoun $\varepsilon n t i$, which, as readers who know Arabic will immediately realize, corresponds to the feminine singular in most other varieties of Arabic and which, as might be predicted, leads to confusion (and even affront) when used in addressing a non-Tunisian male who expects $\varepsilon n t \varepsilon$, the masculine second-person singular in CA/MSA and nearly all dialects.

17. As chapter three of Nelson's book, which treats the samäs Polemic, demonstrates, Muslims do not perceive Qur'anic recitation as associated with music, whether secular or sacred, in any way.

18. The work of the Leeds Project was concerned with "the interplay between written and vernacular Arabic" among educated speakers in Egypt and the Levant (Mitchell 1980: 92). The ground-breaking work that grew out of the project remains ultimately quite problematic, I contend, for at least two very different reasons. First, the convenience sample from which data were elicited and the sorts of data gathered were far too heterogeneous to permit any more than the broadest generalizations at either the social or the linguistic level (cf. Walters 1989: 168). Second and especially significant in light of this paper's discussion of taxonomies, the object of description, labeled Educated Spoken Arabic, likely remains more a set of practices than a focused variety although it was treated as the latter in the research. Such a reification of the phenomena to be investigated, in many ways a result of the linguistic and sociolinguistic thinking of the time, reminds us of the need for new ways of theorizing the complex links between language and society. Similar criticism can be leveled at all discussions of triglossia or levels of Arabic in the sociolinguistic literature on this language.

19. Elarbi (1997) described the ways in which many immigrants to the city of Tunis belonging to the professional class seek to suppress linguistic features associated with stigmatized regional or social varieties of Tunisian Arabic as well as those taken to index beldi identity, that is, membership of the powerful old families of Tunis, often linked to the Ottoman period in Tunisian history.

\section{References}

Al-Ja'aaiibii, Faadel (1997). Famiilya. Tuunis: Dar Al-Januub. Al-Jabaalii, Taufiiq (1997). Klaam Al-liil. Tuunis: Dar Al-Januub. 
Attia, Abdelmajid (1966). Differents registres de l'emploi de l'arabe en Tunisie. Revue Tunisienne de Sciences Sociales 8, 115-134.

Badawi, S. (1973). Mustawayaat al-Sarbiyya al-muGaașira fii mișr. Cairo: Daar Al-MaYaarif.

Balegh, Hédi (1997). Le Petit Prince, avec des dessins de l'auteur. Traduit en arabe tunisien par Hédi Balegh. Tunis.

Bourdieu, Pierre (1991). Language and Symbolic Power. Cambridge, MA: Harvard University Press.

Boussofara-Omar, Naïma (1999). Arabic diglossic switching in Tunisia: an application of Myers-Scotton's MLF model. Unpublished dissertation, University of Texas at Austin.

Douglas, Allen; and Malti-Douglas, Fedwa (1994). Arab Comic Strips: Politics of an Emerging Mass Culture. Bloomington and Indianapolis: Indiana University Press.

Elarbi, Naima (1997). Face and politeness in traditional and modern Tunisia: an application of Brown and Levinson's politeness theory. Unpublished dissertation, University of Texas at Austin.

El-Hassan, Shahir (1977). Educated Spoken Arabic in Egypt and the Levant: a critical review of diglossia and related concepts. Archivum Linguisticum (n.s.) 8, 112-132.

Ferguson, Charles (1959a). The Arabic koine. Language 35, 616-630.

- (1959b). Diglossia. Word 15, 325-340.

- (1966). On sociolinguistically oriented language surveys. Linguistic Reporter 8(4), 1-3.

- (1967). National sociolinguistic profiles. In Sociolinguistics, William Bright (ed.), 309-324. The Hague: Mouton.

- (1987). Standardization as language spread. In Georgetown University Roundtable on Languages and Linguistics, Peter Lowenberg (ed.), 119-132. Washington, D.C.: Georgetown University Press. (Reprinted [1997]. In Structuralist Studies in Arabic Linguistics, R.K. Belnap and N. Haen [eds.], 69-80. Leiden: Brill.)

-(1991). Diglossia revisited. Southwest Journal of Linguistics: The Journal of the Linguistic Association of the Southwest 10(1), 214-234.

- (1994). Dialect, register, and genre: working assumptions about conventionalization. In Sociolinguistic Perspectives on Register, Douglas Biber and Edward Finegan (eds.), 15-30. Oxford: Oxford University Press.

Fishman, Joshua (1967). Bilingualism with and without diglossia; diglossia with and without bilingualism. Journal of Social Issues 23(2), 29-38.

-(1971). La Sociolinguistique. Paris: Nathan.

Gal, Susan; and Irvine, Judith (2000). Language ideology and linguistic differentiation. In Regimes of Language: Ideologies, Polities, and Identities, Paul Kroskrity (ed.), 35-83. Santa Fe, NM: School of American Research Press.

Garmadi, Salah (1968). La situation linguistique actuelle en Tunisie: problèmes et perspectives. Revue Tunisienne des Sciences Sociales 13, 13-24.

Gliouïz, Azaiez (1995). L'Humor: Miroir caché de la société, Etude sur la presse humoristique en Tunisie. Tunis: l'Or du Temps.

Goody, Jack (1968). Introduction. In Literacy in Traditional Societies, Jack Goody (ed.), 1-26. Cambridge: Cambridge University Press.

Halliday, M.A.K.; and Ruqaiya Hasan (1989). Language, Context, and Text: Aspects of Language in a Social-Semiotic Perspective. Oxford: Oxford University Press.

Hamzaoui, Rachid (1970.) L'arabisation au ministère de l'Intérieur: la brigade de la circulation de la Garde nationale. Cahiers du CERES (Centre d'etudes et de Recherches Economiques et Sociales) 3, 11-73.

Higher Standards for Tunisians (1994). http://www.tunisiaonline.com/html/society3.html. (06.27.00).

Hymes, Dell (1973). Speech and language: on the origins and foundations of inequality among speakers. Daedalus 2(3), 59-85. 
Kaye, Alan (1972). Remarks on diglossia: well-defined vs. ill-defined. Linguistics 81, 30-48.

Le Page, R.B. (1978). "Projection, focussing, diffusion" or, steps toward a sociolinguistic theory of language, illustrated from the sociolinguistic survey of multilingual communities, stages I: Cayo District, Belize (formerly British Honduras) and II: St. Lucia. School of Education, St. Augustine, Trinidad. Society for Caribbean Linguistics Occasional Papers 9. (Reprinted [1980]. In York Papers in Linguistics 9.)

-; and Tabouret-Keller, Andrée (1985). Acts of Identity: Creole-based Approaches to Language and Identity. Cambridge: Cambridge University Press.

Maamouri, Mohamed (1973). The linguistic situation in independent Tunisia. American Journal of Arabic Studies 1, 50-56.

Mahmoud, Youssef (1986). Arabic after diglossia. In The Fergusonian Impact: In Honor of Charles A. Ferguson on the occasion of his 65th Birthday, Joshua Fishman et al. (eds.), vol.1, From Phonology to Society, 239-251. Berlin: Mouton de Gruyter.

Marçais, William (1930). La diglossie arabe. L'Enseignement public: Revue pédagogique 104(12), 401-409. (Reprinted [1961]. In Articles et Conferences, W. Marçais, 83-87. Paris: Arienne-Maisonneuve.)

-(1931a). La langue arabe dans l'Afrique du Nord. L'Enseignement public: Revue pédagogique 105(1), 20-39. (Reprinted [1961]. In Articles et Conferences, W. Marçais, 88-101. Paris: Arienne-Maisouneuve.)

- (1931b). L'arabe écrit et l'arabe parlé dans l'enseignment secondaire. L'Enseignement public: Revue pédagogique 105(2), 121-133. (Reprinted [1961], In Articles et Conferences, W. Marçais, 102-110. Paris: Arienne-Maisonneuve.)

Meiseles, Gustav (1979). Informal written Arabic: a preliminary evaluation of data. Israel Oriental Studies 9, 272-314.

-(1980). Educated Spoken Arabic and the Arabic language continuum. Archivum Linguisticum 11(n.s.) (2), 118-148.

Mitchell, T. F. (1980). Dimensions of style in a grammar of Educated Spoken Arabic. Archivum Linguisticum 9(n.s.) (2), 89-106.

-(1982). More than a matter of "writing with the learned, pronouncing with the vulgar." In Standard Languages, Spoken and Written, W. Haas (ed.), 122-155. Manchester: Manchester University Press.

- (1986). What is Educated Spoken Arabic? International Journal of the Sociology of Language 61, 7-32.

Muhawi, Ibrahim (1994). The metalinguistic joke: sociolinguistic dimensions of an Arabic folk genre. In Arabic Sociolinguistics: Issues and Perspectives. Yasir Suleiman (ed.), 155-176. Richmond, Surrey: Curzon.

Myers-Scotton, Carol (1993a). Social Motivations for Codeswitching: Evidence from Africa. Oxford: Oxford University Press.

-(1993b). Duelling Languages: Grammatical Structure in Codeswitching. Oxford: Oxford University Press.

Nelson, Kristina (1985). The art of reciting the Qur'an. Austin: University of Texas Press.

Ochs, Elinor (1979). Planned and unplanned discourse. In Syntax and Semantics 12, Talmy Givón (ed.), 51-80. New York: Academic Press.

Ounali, Habib (1970). La langue des étudiants. Cahiers du CERES (Centre d'Etudes et de Recherches Economiques et Sociales) 3, 167-213.

République Tunisienne (1996). Recensement Général de la Population et de l'Habitat de 1994: Caractèristiques d'Education, Tableaux Statistiques, République Tunisienne, Ministère du Developpement Economique, Institut National de la Statistique. Tunis: Institut National de la Statistique, preliminary internal report. 
Schultz, David (1981). Diglossia and variation in formal spoken Arabic in Egypt. Unpublished Ph.D. dissertation, University of Wisconsin-Madison.

Sebag, Paul (1996). Histoire des juifs de Tunisie: Des origines à nos jours. Paris: L'Harmattan. Walters, Keith (1989). Social change and linguistic variation in Korba, a small Tunisian town. Unpublished dissertation, University of Texas at Austin.

- (1996a). Diglossia, linguistic variation, and language change. In Perspectives on Arabic Linguistics VIII. Mushira Eid (ed.), 157-197. Philadelphia and Amsterdam: Benjamins.

- (1996b). Gender, identity, and the political economy of language: Anglophone wives in Tunisia. Language in Society 25, 515-556.

- (1996c). Intrasentential codeswitching in diglossic settings and its implications for linguistic variation and language change. In Sociolinguistic Variation: Data, Theory, and Analysis: Selected Papers from NWAV23 at Stanford, Jennifer Arnold, Renée Blake, Brad Schwenter, and Julie Solomon (eds.), 401-416. Stanford, CA: CSLI.

Woolard, Kathryn A. (1998). Introduction: language ideology as a field of inquiry. In Language Ideologies: Practice and Theory. Bambi Schieffelin, Kathy Woolard, and Paul Kroskrity (eds.), 3-47. Oxford and New York: Oxford University Press. 
Copyright of International Journal of the Sociology of Language is the property of De Gruyter and its content may not be copied or emailed to multiple sites or posted to a listserv without the copyright holder's express written permission. However, users may print, download, or email articles for individual use. 